\title{
PENGARUH PEMBERIAN MINYAK BUAH MERAH (Pandanus conoideus) TERHADAP STRES OKSIDATIF SEL ENDOTEL YANG DIPAPAR DENGAN SERUM PENDERITA MALARIA FALCIPARUM DAN NETROFIL INDIVIDU SEHAT
}

\section{THE EFFECT OF RED FRUIT OIL (Pandanus conoideus) ON OXIDATIVE STRESS OF ENDOTHELIAL CELLS EXPOSED TO MALARIA FALCIPARUM PATIENT SERUM AND HEALTHY DONOR NEUTROPHIL}

\author{
Yunita Armiyanti ${ }^{*}$, Loeki Enggar Fitri**, Edi Widjajanto*** \\ * Laboratorium Parasitologi Fakultas Kedokteran Universitas Jember \\ ** Laboratorium Parasitologi Fakultas Kedokteran Universitas Brawijaya Malang \\ *** Laboratorium Patologi Klinik Fakultas Kedokteran Universitas Brawijaya Malang
}

\begin{abstract}
Complication in Plasmodium falciparum malaria is associated with endothelial damage and overproduction of free radicals (oxidative stress) by activated neutrophils and endothelial cells. Red fruit (Pandanus conoideus) oil has a very high antioxidant content, therefore it may neutralize free radicals and prevent endothelial damage. The aim of this research is to prove that red fruit (Pandanus conoideus) oil reduce Reactive Oxygen Intermediate (ROI) production of endothelial cells exposed to severe malaria patient serum and neutrophils from healthy donor. Endothelial cells from human umbilical veins were coincubated with serum from severe malaria patient and with neutrophils from healthy donor (positive control group). HUVEC's normal was used as negative control, where as the experimental groups were given with red fruit oil in different concentrations (2.8\%, 5.7\% dan $11.3 \%$ ). The Reactive Oxygen Intermediate (ROI) production of endothelial cells was semiquantitatively measured by using NBT-reduction assay and the score of ROI was counted. The results were statistically analyzed with ANNOVA $(p<0.01)$. The rate of ROI production of endothelial cells was markedly increased after incubation with patient serum and neutrophils. The red fruit oil in different concentrations could significantly decrease the rate of $\mathrm{ROI}$ production of cells. There was negative correlation between red fruit oil concentration with $R O I$ production (Spearman's analyzed, $p<0.01$, Correlation Coeff $=-0.950$ ), $R O$ I score (Correlation Coeff $=-0.928$ ). It is concluded that red fruit (Pandanus conoideus) oil neutralized oxidative stress of cells by reducing $R O I$ production of endothelial cells exposed to severe malaria patient serum and neutrophils from healthy donor in vitro.
\end{abstract}

Key words: Plasmodium falciparum, endothelial cells, ROI, red fruit oil

\section{PENDAHULUAN}

Infeksi Plasmodium falciparum sering menyebabkan komplikasi pada beberapa organ seperti otak, paru, ginjal, dan gastrointestinal. Pada organ-organ tersebut terjadi anoksia jaringan karena adanya kelainan di mikrovaskuler (1). Di dalam pembuluh kapiler organ-organ tersebut terjadi sekuestrasi eritrosit yang terinfeksi parasit beserta komponen darah lainnya seperti lekosit, monosit, dan platelet, sehingga terjadi obstruksi pembuluh darah $(1,2)$. Selain itu juga terjadi overproduksi sitokin sel-sel fagosit dan sel endotel yang teraktivasi menghasilkan Tumour Necrosis Factor- $\alpha$ (TNF-a), Interleukin-1 (IL-1), Interferon-y (IFN- $\mathrm{Y}$ ), dan radikal bebas seperti Reactive Oxygen Intermediate (ROI), Reactive Oxygen Spesies (ROS), Nitric Oxyde (NO). Pengeluaran mediator di atas sebenarnya bertujuan untuk membunuh parasit, namun karena sifat

Jurnal Kedokteran Brawijaya, Vol. XXIII, No. 1, April 2007 Korespondensi: Yunita A; Lab. Parasitologi FK Unej Jember; Jl. Kalimantan No.23 Jember; Telp: 0331-337877 radikal bebas yang tidak spesifik dapat menyebabkan kerusakan pada jaringan sekitarnya termasuk apoptosis sel endotel $(2,3)$.

Overproduksi radikal bebas pada infeksi malaria menyebabkan keadaan stres oksidatif. Hal ini ditunjukkan dengan adanya peningkatan peroksidasi lipid plasma pada infeksi Plasmodium falciparum yang prosesnya melalui dua mekanisme. Mekanisme yang pertama adalah peningkatan produksi ROS dan yang kedua adalah ketersediaan prooksidan yang meningkat dalam bentuk hemoglobin dan Fe bebas sebagai akibat hemolisis (4). Suatu penelitian dengan menggunakan hewan coba yang diinfeksi dengan Plasmodium berghei dan Plasmodium chabaudi, menunjukkan eritrosit yang terinfeksi mempunyai peroksidasi lipid yang lebih tinggi dibandingkan eritrosit normal. Hal ini dapat digunakan sebagai indikator adanya efek dari stres oksidatif. Peningkatan peroksidasi lipid tersebut berkaitan dengan ROS, terutama anion superoksid dan hidrogen peroksida serta terdapat efek kombinasi yang dipotensiasi oleh Fe melalui pembentukan radikal hidroksil (5). 
Peningkatan radikal bebas tersebut salah satunya berasal dari netrofil. Netrofil berusaha mengeliminasi parasit dengan cara fagositosis dan melepaskan radikal bebas serta enzim-enzim proteolitik. Kemampuan fagositosis dan pengeluaran radikal bebas oleh netrofil diinduksi adanya antibodi yang mengopsonisasi parasit dan adanya sitokinsitokin seperti IFN- $\gamma$, TNF-a, IL-1 $\beta$, dan granulocyte macrophage-colony stimulating factor (GM-CSF) (6). Netrofil membunuh parasit dengan cara membuat kondisi stres oksidatif melalui produksi $\mathrm{O}_{2}$ - di ekstraseluler maupun di dalam vesikel fagositik. Radikal superoksid $\left(\mathrm{O}_{2}^{-}\right)$tersebut dapat membentuk hidrogen peroksida $\left(\mathrm{H}_{2} \mathrm{O}_{2}\right)$ yang dengan mudah menembus membran dan masuk ke dalam tubuh parasit dan bereaksi dengan $\mathrm{Fe}$ atau $\mathrm{Cu}$ (reaksi Fenton) membentuk radikal hidroksil $\left(\mathrm{OH}^{-}\right)$yang bersifat toksik dan merusak. Proses fagositosis tersebut menimbulkan masalah apabila netrofil yang teraktivasi jumlahnya banyak dan proses fagositosisnya berlangsung lama, sehingga menimbulkan stres oksidatif pada jaringan di sekitarnya termasuk pada sel-sel endotel (7).

Dengan adanya keterlibatan stres oksidatif di dalam patomekanisme malaria berat dengan komplikasi, maka dalam penatalaksanaan malaria berat tidak cukup hanya dengan pemberian obat-obat antimalaria saja. Selain obatobat antimalaria perlu diberikan terapi adjuvant yang dapat mencegah dan menghambat timbulnya komplikasi yang lebih berat, salah satunya adalah dengan pemberian antioksidan. Pemberian terapi klorokuin yang dikombinasi dengan ascorbic acid pada hewan coba dapat mengurangi stres oksidatif dan menstabilkan membran eritrosit (8). Klorokuin dan $\mathrm{N}$-Acetyl Cystein mempunyai efek sinergis dalam menurunkan derajat parasitemia dan menurunkan aktifitas radikal bebas (9). Penelitian secara in vitro menunjukkan bahwa pemberian ascorbic acid dan tocopherol pada kultur sel endotel (Human Umbilical Veins Endothelial Cells) yang dipapar serum penderita infeksi $P$. falciparum dan netrofil dapat mengurangi apoptosis pada sel-sel endotel (10).

Salah satu sumber antioksidan yang sangat potensial adalah Pandanus conoideus atau yang lebih dikenal dengan buah merah. Buah merah mengandung senyawa antioksidan yang sangat tinggi meliputi karoten (12.000 ppm), betakaroten (700 ppm), tocopherol (11.000 ppm) dan alpha-tocopherol (500 ppm) (11).

Berdasarkan uraian di atas diketahui adanya peranan radikal bebas dalam patomekanisme terjadinya komplikasi pada malaria falciparum, sehingga diharapkan pemberian antioksidan dapat menghambat komplikasi tersebut. Sampai saat ini belum dilakukan penelitian terhadap potensi antioksidan buah merah terhadap keadaan stres oksidatif pada infeksi Plasmodium falciparum. Pada penelitian ini akan diteliti apakah pemberian minyak buah merah dapat menetralisir keadaan stres oksidatif dengan menurunkan produksi ROI sel endotel secara in vitro. Pada penelitian ini digunakan netrofil yang diaktivasi dengan serum penderita malaria falciparum berat yang mengandung antigen parasit dan sitokin-sitokin.

\section{METODE}

Penelitian ini menggunakan desain eksperimen murni (true experimental) secara in vitro dengan menggunakan kultur HUVECs (Human Umbilical Vein Endothelial Cells) sebagai model.

\section{Cara Pengambilan Umbilikus}

Umbilikus diambil dari bayi yang lahir melalui persalinan caesar dengan kriteria inklusi adalah kehamilan fisiologis dan bukan kehamilan dengan preeklamsi/eklamsi, kehamilan dengan infeksi, hipertensi, dan diabetes mellitus. Kultur sel endotel diperlakukan tidak lebih dari 12 jam setelah waktu kelahiran. Disiapkan botol berisi cord solution dari refrigerator (suhu $4^{\circ}$ ). Segera setelah kelahiran, umbilikus dipotong sepanjang $\pm 20 \mathrm{~cm}$ dan langsung dimasukkan ke dalam larutan cord solution.

\section{Pembuatan kultur HUVECs}

Pembuatan kultur HUVECs dilakukan berdasarkan metode dari Morgan (1996) yang telah dimodifikasi oleh laboratorium Biomedik Fakultas Kedokteran Universitas Brawijaya (12). Umbilicus dibersihkan dengan alkohol dari jaringan dan bekuan darah. Kemudian dimasukkan kanul pada salah satu ujung vena sedalam $\pm 1,5 \mathrm{~cm}$ dan diikat seerat mungkin. Vena dicuci dengan PBS dengan menggunakan pipet, setelah bersih ujung yang tidak berkanul diklem kuat. Delapan mililiter collagenase (SIGMA, C-6885) dimasukkan ke dalam vena dengan spuit tetap terpasang dan diklem, kemudian didekap dengan tangan selama \pm 8 menit. Cairan dari dalam umbilikus disentrifugasi $1600 \mathrm{rpm}$ selama 8 menit. Pelet dikocok-kocok agar homogen dengan medium kultur sebanyak $4 \mathrm{ml}$. Medium kultur terdiri dari serum free (Medium 199 (SIGMA M-5017), gentamycin, bicarbonat phenol red, glutamine) ditambah newborn calf serum (NCS)(SIGMA, N-4637). Pelet dimasukkan ke dalam well sebanyak 24 buah yang sebelumnya diberi gelatin, media ditumbuhkan di inkubator sampai monolayer.

\section{Isolasi Serum dari Darah Penderita Malaria falciparum Berat}

Penderita yang akan diambil darahnya diminta kesediaannya setelah mendapat penjelasan lebih dahulu (informed concern). Darah diambil dari sampel penderita malaria falciparum berat (malaria falciparum dengan komplikasi malaria otak dan anemia berat) dengan cara aseptis. Serum diambil secara steril dan disentrifus dengan kecepatan $3000 \mathrm{rpm}$ selama 10 menit. Supernatan (serum) diambil dan disimpan dalam suhu $-4^{\circ} \mathrm{C}$ (13).

\section{Isolasi Netrofil dari Donor Orang Sehat}

Darah diambil dari donor organ sehat sebanyak 10 $\mathrm{ml}$ secara aseptis, setelah diberi penjelasan lebih dahulu 
(informed consent). HISTOPAQUE densitas 1,119 (SIGMA, 11191) sebanyak $3 \mathrm{ml}$ dimasukkan kedalam tabung sentrifus $15 \mathrm{ml}$. Secara perlahan dilapiskan HISTOPAQUE densitas 1,077 (SIGMA, 1077-1) sebanyak $3 \mathrm{ml}$ di atas HISTOPAQUE densitas 1,119. Secara hati-hati dilapiskan darah sebanyak $6 \mathrm{ml}$ pada bagian atas. Kemudian diisentrifus pada $700 \times \mathrm{g}$ selama 30 menit pada suhu ruangan. Lapisan cincin kedua yang berisi sel-sel PMN diaspirasi dan dengan hati-hati dipindah ke tabung dan ditambahkan dengan PBS $10 \mathrm{ml}$, kemudian disentrifus dengan kecepatan 200 x g selama 10 menit. Supernatan dibuang, pelet dicuci lagi dengan PBS seperti prosedur di atas sebanyak dua kali, kemudian tambahkan PBS secukupnya (6).

Pemaparan Kultur HUVECs dengan Serum Penderita Malaria dan Netrofil serta Pemberian Minyak Pandanus conoideus konsentrasi 2,8\%, 5,7 \% dan 11,3\%

Minyak Pandanus conoideus dengan konsentrasi $2,8 \%, 5,7 \%$, dan $11,3 \%$ dimasukkan secara bersamaan dengan campuran serum penderita malaria dengan netrofil normal (hitung sel sebanyak 1000 netrofil per $\mu l)$ ke dalam masing-masing well yang berisi kultur HUVECs yang telah monolayer. Setiap well diberi $0,5 \mu \mathrm{L}$ ekstrak buah merah dalam $500 \mu \mathrm{L}$ campuran serum penderita malaria dengan netrofil normal. Kultur HUVECs diinkubasi dengan campuran tersebut selama 90 menit pada suhu $37^{\circ} \mathrm{C}$, kemudian dibilas tiga kali dengan HEPES-buffered saline pada $\mathrm{pH} 7,4$ dan diinkubasi dengan medium complete selama 4,5 jam. Setelah dibilas tiga kali dengan HEPESbuffered saline dilakukan pemeriksaan ROI sel endotel (10).

\section{Pengukuran Produksi ROI Sel Endotel}

Kultur sel endotel di atas cover slip dalam well 18 yang sudah mendapat perlakuan dipersiapkan. Medium biakan dibuang, ditambahkan 50 $\mu$ PMA (Biomedicals, 151864) $1250 \mathrm{ng} / \mathrm{ml}, 400 \mu \mathrm{l}$ NBT (SIGMA, N-6876) $1 \mathrm{mg} / \mathrm{ml}$, dan $50 \mu \mathrm{HBSS}$, setelah itu diinkubasi selama 1 jam dalam inkubator $37^{\circ} \mathrm{C}$ dan $\mathrm{CO} 25 \%$. Supernatan dibuang dan sel endotel dicuci dengan PBS, difiksasi dengan metanol selama 30 detik kemudian dicuci dengan PBS dan ditambahkan Neutral Red Solution 2\% (SIGMA,N-2889) selama 15 menit. Terakhir kultur dicuci dengan air mengalir dan dikeringkan (13).

\section{Analisis Data}

Data-data yang diperoleh dianalisis secara statistik dengan menggunakan ANOVA untuk mengetahui adanya pengaruh/perbedaan bermakna pada berbagai perlakuan. Selanjutnya dilakukan uji LSD untuk mengetahui perbedaan nyata antar perlakuan. Untuk mengetahui adanya hubungan antar perlakuan digunakan uji korelasi non parametrik Spearman's $(p<0,01)$.

\section{HASIL PENELITIAN}

Hasil penghitungan persentase produksi ROI sel endotel secara semikuantitatif pada kelompok kontrol dan kelompok perlakuan menunjukkan adanya penurunan produksi ROI pada kelompok perlakuan dengan pemberian minyak buah merah konsentrasi $2,8 \%, 5,7 \%$, dan $11,3 \%$. Hasil penghitungan tersebut dapat dilihat pada Tabel 1 dan Grafik rerata persentase produksi ROI sel endotel pada Gambar 1.

Dari grafik pada Gambar 1, menunjukkan persentase produksi ROI tertinggi terjadi pada kelompok kontrol positif. Pada kelompok perlakuan yang diberi minyak buah merah berbagai konsentrasi menunjukkan makin tinggi konsentrasi makin sedikit produksi ROI sel endotel, bahkan pada konsentrasi tertinggi $(11,3 \%)$ produksi ROlnya mendekati nol (mendekati kontrol negatif).

Hasil uji dengan analisis statistik One Way ANOVA menunjukkan terdapat pengaruh yang signifikan $(p<0.01)$ pada kelompok kontrol maupun kelompok perlakuan terhadap persentase produksi ROI sel endotel. Oleh karena itu dilanjutkan dengan uji beda antar kelompok (LSD) yang menunjukkan terdapat perbedaan persentase produksi ROI yang signifikan $(p<0.01)$ antara kelompok kontrol negatif dengan kelompok kontrol positif. Pada kelompok perlakuan yang diberi minyak buah merah berbagai konsentrasi yaitu $2,8 \%, 5,7 \%$, dan $11,3 \%$ berbeda nyata dengan kelompok kontrol positif yang tidak diberi minyak buah merah, namun tidak berbeda nyata dengan kelompok kontrol negatif. Hal tersebut berarti pemberian minyak buah merah memberikan pengaruh terhadap produksi $\mathrm{ROI}$ sel endotel hingga mendekati nilai normal (kontrol negatif). Sedangkan antar konsentrasi buah merah, yaitu konsentrasi 2,8\%, 5,7 \%, dan $11,3 \%$ tidak menunjukkan beda nyata.

Berdasarkan analisis statistik korelasi non parametrik menggunakan Spearman's ( $p<0.01$, Correlation Coefficient $=-1$ ) didapatkan bahwa terdapat hubungan negatif antara berbagai konsentrasi minyak buah merah $(2,8 \%, 5,7 \%$, dan $11,3 \%)$ terhadap persentase produksi ROI sel endotel $(r=-0,950 p=0,00)$. Hal tersebut menunjukkan bahwa semakin besar pemberian konsentrasi minyak buah merah pada sel endotel yang dipapar dengan serum penderita malaria falciparum berat dan netrofil normal semakin kecil produksi ROInya.

Produksi ROI sel endotel secara kualitatif juga dihitung dengan sistim skoring berdasarkan penelitian dari Tjahajati, 2006. Skor ROI sel endotel dihitung dengan cara menjumlahkan besarnya skor yang dicapai pada masingmasing kelompok. Skor 0 jika pada sel endotel tidak terbentuk formazan, skor 1 jika pada sebagian sel endotel terbentuk formazan dan skor 2 jika pada seluruh sel endotel terbentuk formazan (Gambar 4) (14). Hasil penghitungan dapat dilihat pada Gambar 2. 
Berdasarkan diagram pada Gambar 2, hasil penghitungan skor $\mathrm{ROI}$ memberikan gambaran yang serupa dengan persentase produksi ROI sel endotel. Skor tertinggi didapatkan pada kelompok kontrol positif dan dengan pemberian minyak buah merah, skornya semakin menurun.

Hasil uji analisis statistik dengan One Way ANOVA menunjukkan adanya perbedaan yang nyata antara semua kelompok dengan jumlah skor ROI sel endotel $(p<0,01)$. Berdasarkan uji beda antar kelompok dengan menggunakan analisis statistik LSD, didapatkan perbedaan yang signifikan antara kontrol positif dengan kelompok perlakuan yang diberi buah merah $(p<0,01)$, namun antar konsentrasi buah merah, yaitu konsentrasi 2,8\%, 5,7 \%, dan $11,3 \%$ tidak menunjukkan beda nyata.

Tabel 1. Efek Berbagai Konsentrasi Minyak Buah Merah (BM) terhadap Produksi ROI Sel Endotel yang Dipapar Serum Penderita Malaria Falciparum Berat dan Netrofil Normal

\begin{tabular}{|c|c|c|c|}
\hline No. & Kelompok & Jumlah Sel Endotel & Produksi ROI (X士SD) \% \\
\hline 1 & Kontrol negatif & 464 & $0,00 \pm 0,00$ \\
\hline 2 & Kontrol positif & 464 & $53,05 \pm 9,21$ \\
\hline 3 & Kelompok I (2,8\%) & 399 & $12,21 \pm 1,04$ \\
\hline 4 & Kelompok II (5,7 \%) & 418 & $5,44 \pm 1,26$ \\
\hline 5 & Kelompok III $(11,3 \%)$ & 328 & $3,78 \pm 0,63$ \\
\hline
\end{tabular}

Keterangan :

Kontrol - : HUVECs

Kontrol + : HUVECs + serum malaria + netrofil

Kel. I : HUVECs + serum malaria + netrofil + BM 2,837\%

Kel. II : HUVECs + serum malaria + netrofil + BM 5,673\%

Kel. III : HUVECs + serum malaria + netrofil + BM 11,334\%

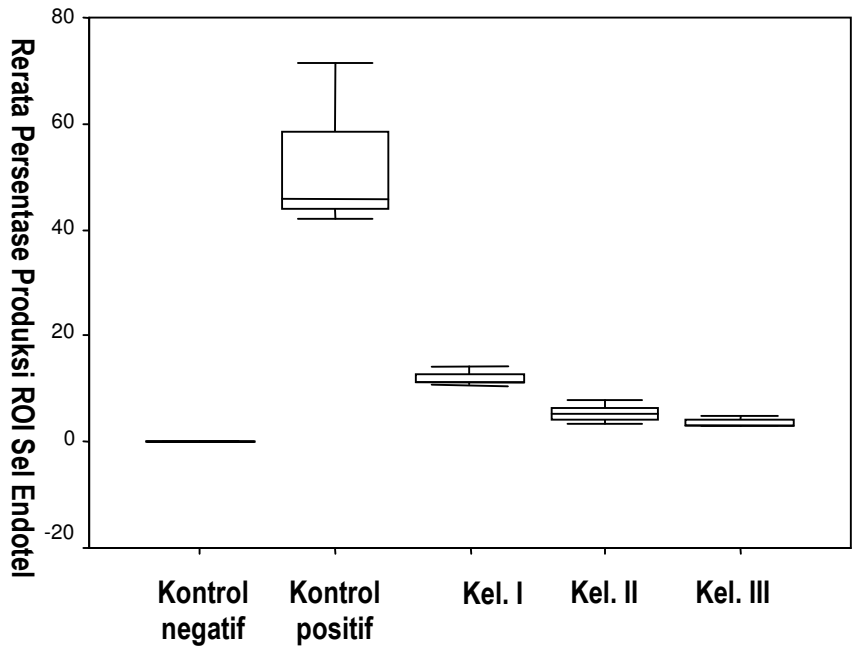

KELOMPOK

Keterangan :

Kontrol - : HUVECs

Kontrol + : HUVECs + serum malaria + netrofil

Kel. I : HUVECs + serum malaria + netrofil + BM 2,837\%

Kel. II : HUVECs + serum malaria + netrofil +BM 5,673\%

Kel. III : HUVECs + serum malaria + netrofil +BM 11,334\%

Gambar 1.Diagram Efek Berbagai Konsentrasi Minyak Buah Merah (BM) terhadap Rerata Persentase Produksi ROI Sel Endotel yang Dipapar Serum Penderita Malaria Falciparum Berat dan Netrofil Normal $(p<0,01)$ 


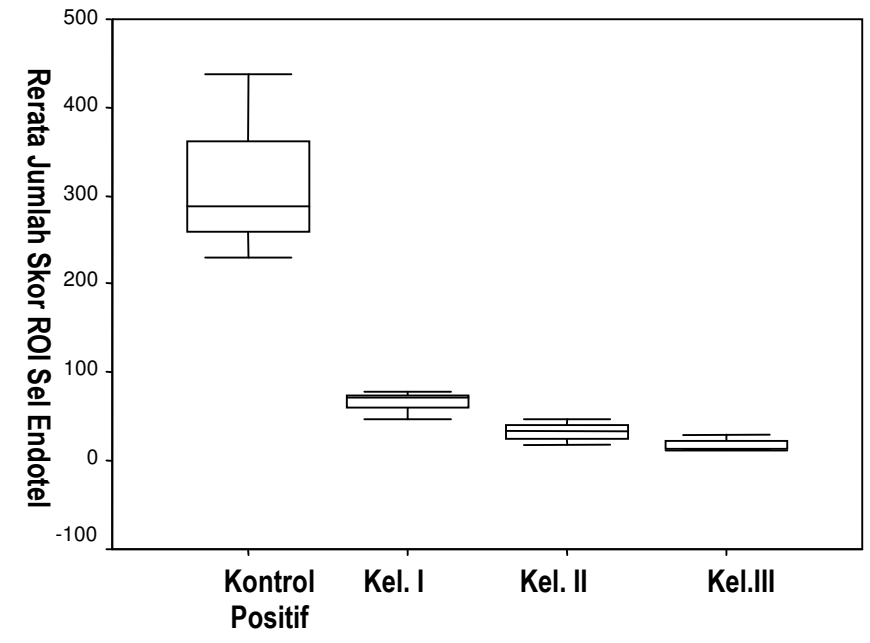

Keterangan :

Kontrol - : HUVECs

Kontrol + : HUVECs + serum malaria + netrofil

Kel. I : HUVECs + serum malaria + netrofil + BM 2,837\%

\section{KELOMPOK}

Gambar 2. Diagram Efek Berbagai Konsentrasi Minyak Buah Merah (BM) terhadap Skor ROI Sel Endotel yang Dipapar Serum Penderita Malaria Falciparum Berat dan Netrofil Normal $(p<0,01)$

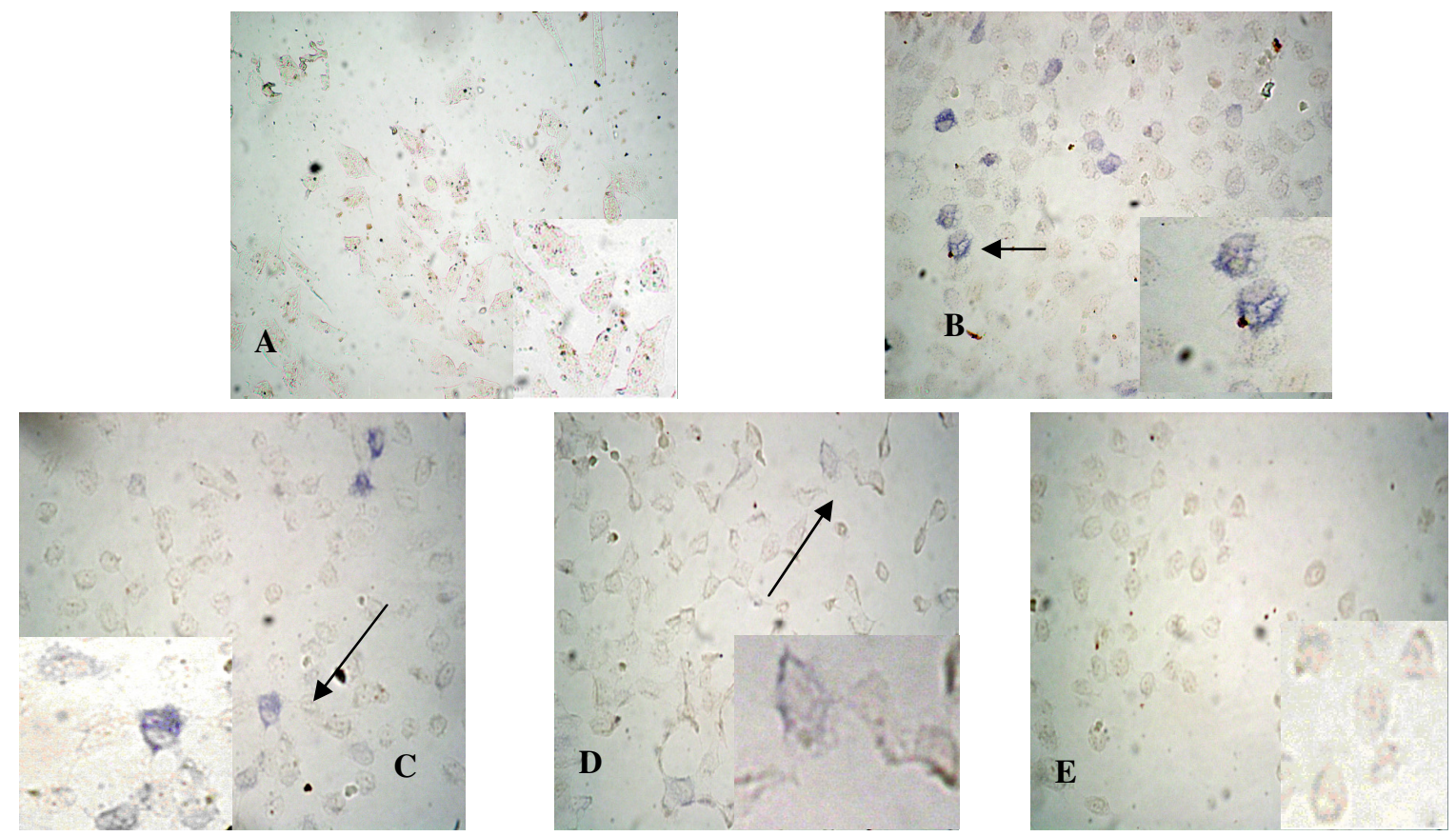

Keterangan :

A. Kontrol negatif : tidak terdapat produksi ROI, semua sel berwarna merah;

B.Kontrol positif: banyak sel endotel yang memproduksi ROI dengan sel berwarna ungu;

C. Kelompok I (minyak buah merah konsentrasi 2,8\%): terjadi penurunan produksi ROI sel endotel dibandingkan kontrol positif

D. Kelompok II (minyak buah merah konsentrasi 5,7\%): sel endotel yang memproduksi ROI semakin sedikit

E. Kelompok III (minyak buah merah konsentrasi 11,3\%) : produksi ROI hampir negatif (mendekati kontrol negatif).

Tanda panah menunjukkan ROI positif dengan warna ungu akibat pembentukan formazan dari reaksi radikal superoksid dengan NBT

Gambar 3. Hasil Sediaan Sel Endotel dengan Pemeriksaan NBT-Reduction Assay (Bio-assay) untuk Melihat Produksi ROI Sel Endotel, Diambil dengan Mikroskop Cahaya Merk Olympus dengan Perbesaran 400X 


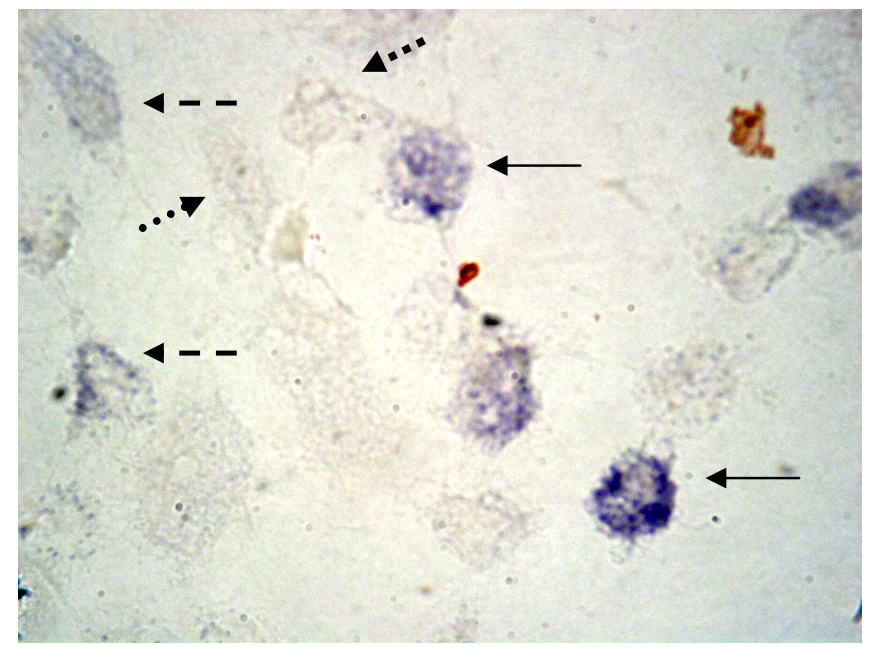

Keterangan :

$(-)$ : sel endotel yang membentuk formazan pada keseluruhan sel (skor2);

( - - ) : sel endotel yang membentuk formazan pada sebagian sel (skor 1);

(-.-) : sel endotel yang tidak membentuk formazan (skor 0).

\section{Gambar 4. Sel Endotel yang Memproduksi ROI dengan Membentuk Formazan Berwarna Ungu pada Sitoplasmanya} (Perbesaran 1000X)

Hubungan antara kelompok perlakuan yang diberi minyak buah merah terhadap jumlah skor ROI dilihat dengan analisis statistik korelasi non parametrik menggunakan Spearman's ( $p<0.01$, Correlation Coefficient $=-1$ ). Berdasarkan analisis tersebut didapatkan hubungan negatif antara kelompok perlakuan dengan jumlah skor ROI ( $r=-$ 0,928). Hal ini berarti bahwa semakin besar konsentrasi buah merah yang diberikan pada sel endotel yang dipapar dengan serum penderita malaria falciparum berat dan netrofil normal semakin kecil skor ROI sel endotel. Dengan analisis yang sama juga dilihat hubungan antara persentase produksi ROI sel endotel terhadap skor ROI dan didapatkan hubungan positif $(r=0,972)$. Hal ini berarti bahwa semakin tinggi persentase produksi ROI pada sel endotel yang dipapar dengan serum penderita malaria falciparum berat dan netrofil normal, maka semakin tinggi pula skor ROlnya.

\section{DISKUSI}

Pada penelitian ini digunakan serum penderita malaria berat dan netrofil normal karena serum tersebut dapat mengaktivasi netrofil untuk mengeluarkan radikal bebas, sehingga terbentuk kondisi stres oksidatif. Seperti telah diteliti sebelumnya, serum penderita malaria mengandung sitokin-sitokin proinflamasi seperti TNF-a, IFN- $\gamma, \quad I L-1 \beta, \quad I L-6, \quad I L-12$, selain itu juga mengandung antibodi spesifik (misal MSA-2), komplemen dan produkproduk metabolit dari parasit malaria $(15,16)$. Substansisubstansi tersebut dapat mengaktivasi netrofil dan meningkatkan kemampuan fagositosisnya. Peningkatan kemampuan fagositosis tersebut dikarenakan TNF-a meningkatkan ekspresi reseptor Fc dan memperkuat ekspresi reseptor komplemen tipe 3. Disamping itu, TNF-a juga dapat memperkuat pelepasan isi granula dan reactive oxygen intermediate (ROI) oleh netrofil, sehingga dapat meningkatkan kemampuan membunuh parasit (6). Hal ini didukung pula oleh penelitian Kumaratilake dan Ferrante, 2000 yang membuktikan bahwa kemampuan fagositosis netrofil tersebut semakin optimal, terutama terhadap merozoite $P$. falciparum, dengan adanya sitokin-sitokin (TNF-a, IFN- $y$, GM-CSF, dan IL-1 $\beta$ ) dan antibodi antimalaria (MSA-2). Disamping itu, secara in vitro lonjakan oksidatif (metabolic/oxidative burst) netrofil normal dapat dipicu oleh eritrosit yang terinfeksi P.falciparum bersama dengan serum yang mengandung antibodi terhadap parasit dan komplemen (17).

Produksi ROI sel endotel setelah dipapar dengan netrofil normal yang diaktivasi oleh serum penderita malaria berat (pada kontrol positif) dibandingkan dengan sel endotel normal (kontrol negatif) menunjukkan adanya perbedaan yang signifikan. Tingginya produksi ROI sel endotel pada kontrol positif menunjukkan bahwa lonjakan oksidatif yang berlebihan dari netrofil yang teraktivasi dapat menciptakan kondisi stres oksidatif pada sel endotel. Hasil penelitian tersebut sejalan dengan penelitian Fitri et al, (2004) yang membuktikan adanya produksi ROI sel endotel yang tinggi setelah dipapar dengan eritrosit terinfeksi $P$. falciparum dan TNF-a (13). Hal ini menunjukkan adanya keterlibatan stres oksidatif dalam patomekanisme malaria $P$. falciparum. 
Produksi ROI oleh sel endotel ditunjukkan dengan terbentuknya formazan yang berupa warna ungu pada sitoplasma sel endotel (Gambar 4). Pembentukan formazan tersebut merupakan hasil reaksi antara radikal superoksid dengan Nitro Blue Tetrazolium (NBT) (7). Sel endotel dapat membentuk ROS seperti: radikal superoksid, hidrogen peroksida, NO, peroksinitrit radikal hidroksil, dan radikal lainnya. Sumber-sumber yang potensial dalam sel endotel untuk memproduksi radikal superoksid (ROI) yang utama adalah NADPH oksidase, selain itu meliputi mitokondria, xanthine oxidase, uncoupled NO synthase, enzim sitokrom P-450. NADPH oksidase sel endotel tersebut memproduksi radikal superoksid intraseluler secara simultan baik pada sel endotel yang teraktivasi maupun yang tidak. Aktivitasnya akan meningkat oleh karena beberapa stimulus diantaranya karena sitokin (TNF-a) dan keadaan inflamasi (18). Produksi ROI sel endotel yang meningkat setelah dipapar dengan netrofil yang teraktivasi kemungkinan melalui dua mekanisme, yaitu 1). terjadi peningkatan produksi radikal superoksid intraseluler sel endotel dari beberapa sumber terutama dari NADPH oksidase. Peningkatan tersebut berpotensi juga meningkatkan pengeluaran radikal superoksid dari sumbersumber yang lain. Sumber-sumber enzimatis tersebut antara lain perubahan xanthine dehydrogenase menjadi xanthine oxidase dengan membentuk $\mathrm{O}_{2}{ }^{-}$melalui oksidasi, mitokondria karena rentan dengan keadaan stres oksidatif dan mekanisme uncoupling eNOS oleh karena degradasi $\mathrm{H}_{4} \mathrm{~B}$ (kofaktor eNOS) oleh $\mathrm{O}_{2}^{-}$(19); 2). netrofil yang teraktivasi akan mengalami peningkatan konsumsi oksigen yang disebut dengan lonjakan respirasi (respiratory burst). Selama proses tersebut oksigen mengalami reduksi secara univalen melalui enzim NADPH oksidase menjadi anion superoksid. Anion superoksid ini merupakan suatu reduktan dengan satu elektron maupun oksidan dengan satu elektron dan dapat melewati membran sel melalui kanal anion. Oleh karena itu pelepasan radikal superoksid ekstraseluler oleh netrofil dapat masuk sel endotel melalui kanal anion (7).

Pemaparan sel endotel dengan netrofil yang teraktivasi dapat menimbulkan efek potensiasi diantara keduanya, sehingga memperkuat kondisi stres oksidatif. Hal ini ditunjukkan dengan adanya produksi $\mathrm{ROI}$ yang sangat tinggi pada kontrol positif $(53,05 \pm 9,21 \%)$. Netrofil yang teraktivasi dapat mensintesa dan mensekresi sitokin dalam jumlah kecil seperti TNF-a, IL-1, IL-6, IL-8, dan GM-CSF. Sitokin-sitokin tersebut dapat bertindak sebagai autokrin maupun parakrin, sehingga meningkatkan kemampuan sitotoksik netrofil sendiri dan dapat mengaktivasi sel sekitarnya termasuk sel endotel. Demikian juga sel endotel yang teraktivasi dapat mensekresi beberapa sitokin dan kemokin seperti IL-8 (neutrophil - activating factor), GMCSF dan Platelet Acivating Factor (PAF). Substansisubstansi tersebut dapat memperkuat aktivitas netrofil dalam mengeluarkan radikal superoksid $(7,20)$. Dengan demikian aktivasi keduanya akan semakin memperkuat kondisi stres oksidatif.

Pada penelitian ini dengan pemberian minyak buah merah berbagai konsentrasi $(2,8 \%, 5,7 \%$, dan $11,3 \%)$, produksi ROI sel endotel menurun secara nyata dibandingkan dengan kontrol positif $(p<0,01)$. Demikian pula dengan hasil penghitungan skor $\mathrm{ROI}$ sel endotel untuk menilai produksi $\mathrm{ROI}$ sel endotel secara kualitatif (berdasarkan pembentukan formazan) menunjukkan hasil yang sesuai. Hasil penelitian ini menunjukkan bahwa minyak buah merah mempunyai aktivitas antioksidan, sehingga dapat menetralisir ROI dan menurunkan keadaan stres oksidatif pada sel endotel. Dari hasil penelitian yang dilakukan oleh Budi, (2005) ternyata minyak buah merah mempunyai kandungan antioksidan tokoferol dan karoten yang sangat tinggi dibandingkan dengan buah dan sayur yang mengandung antioksidan yang sama (11). Nilai total karoten sari buah merah rerata mencapai 12.233,34 ppm, sedangkan kandungan betakarotennya mencapai 300 ppm pada sampel dengan berat rerata 0,24 gram. Kandungan tokoferolnya mencapai 10.000 ppm dengan kandungan atokoferol mencapai $500 \mathrm{ppm}$. Hal ini sesuai dengan penelitian yang dilakukan oleh van Tits et al, (2000) bahwa a-tokoferol dapat menghambat secara signifikan pengeluaran radikal superoksid oleh sel-sel PMN yang diinduksi dengan phorbol ester (21). Demikian pula dengan penelitian oleh Harper et al, (2002) bahwa pemberian antioksidan vitamin $\mathrm{E}$ dan vitamin $\mathrm{C}$ pada penderita vaskulitis karena antineutrophil cytoplasmic antibody (ANCA) menurunkan pembentukan radikal superoksid oleh netrofil (22).

Kandungan beta-karoten dalam minyak buah merah dapat melindungi pertahanan sel dari kerusakan akibat ROS. Beta-karoten dapat menetralisir reactive oxygen spesies (ROS) karena mempunyai kemampuan untuk meredam (quenching) radikal peroksil dan menangkap (scavenger) singlet oksigen, terutama pada keadaan tekanan oksigen yang rendah (23). Weitberg et al dalam Chew, (1993) melaporkan bahwa beta-karoten menurunkan kerusakan kromosom yang disebabkan oleh aktivitas fagositosis dan pembentukan metabolit oksigen pada selsel PMN (24).

Dalam menetralisir ROS, tokoferol mempunyai mekanisme antioksidan maupun non-antioksidan $(25,26)$. Dalam kapasitasnya sebagai antioksidan, tokoferol dapat meredam dan bereaksi dengan singlet oksigen, selain itu pada pelarut organik tokoferol dapat bereaksi dengan radikal superoksid secara lambat membentuk radikal tokoferoksil. Radikal tokoferoksil tersebut dapat bereaksi dengan radikal peroksil membentuk produk non radikal melalui reaksi sebagai berikut (7) :

$$
\begin{aligned}
& \mathrm{O}_{2}^{-}+\mathrm{ToCH} \rightarrow \mathrm{ToC}^{-}+\mathrm{HO}_{2}{ }^{-} \\
& \mathrm{LO}_{2} \text { + }+\mathrm{TOC}^{-} \text {-----> TocOOL }
\end{aligned}
$$


Mekanisme non-antioksidan tokoferol diantaranya meliputi menghambat aktivasi NADPH oksidase melalui penghambatan translokasi membran dan fosforilasi dari p47phox, sehingga mencegah pembentukan radikal superoksid. Vitamin $\mathrm{E}$ yang bersifat hidrofobik dan terdapat di membran sel dapat merubah NADPH oksidase yang berada di membran melalui penghambatan pembentukan kompleks subunit-subunit NADPH oksidase (27). Disamping itu tokoferol (alpha-tokoferol) juga dapat menghambat pembentukan radikal superoksid pada monosit dan netrofil melalui mekanisme yang melibatkan penghambatan terhadap protein kinase $C$ (PKC). Penghambatan tersebut terjadi melalui pencegahan terhadap autofosforilasi enzim PKC atau melalui defosforilasi PKC oleh protein fosfatase yang diaktivasi oleh alpha-tokoferol $(23,24)$.

Pada penelitian ini berdasarkan analisis statistik korelasi non parametrik menggunakan Spearman's didapatkan bahwa terdapat hubungan negatif antara berbagai konsentrasi minyak buah merah $(2,8 \%, 5,7 \%$, dan $11,3 \%$ ) terhadap persentase produksi ROI sel endotel $(r=$ $-0,950 p=0,00)$. Demikian pula dengan skor ROI sel endotel juga didapatkan hubungan negatif $(r=-0,928)$. Hal ini menunjukkan bahwa semakin tinggi konsentrasi buah merah yang diberikan, maka semakin rendah produksi ROI dan skor ROI sel endotel. Hubungan ini secara in vitro membuktikan minyak buah merah yang mengandung aktivitas antioksidan terutama kandungan tokoferol dan karotennya dapat menurunkan stres oksidatif yang terjadi pada infeksi malaria falciparum berat. Hasil penelitian ini sesuai dengan penelitian sebelumnya mengenai efek antioksidan secara in vivo maupun in vitro pada infeksi malaria. Pemberian terapi klorokuin yang dikombinasi dengan ascorbic acid pada hewan coba dapat mengurangi stres oksidatif dan menstabilkan membran eritrosit (8). Pada penelitian yang dilakukan oleh Iskandar (2004) menunjukkan adanya efek sinergis dari klorokuin dan $\mathrm{N}$ Acetyl Cystein dalam menurunkan aktifitas radikal bebas mencit yang diinfeksi dengan $P$. berghei (9). Demikian pula dengan kombinasi klorokuin dan vitamin $C$ memberikan efek peningkatan fungsi fagositosis sel makrofag peritoneal dan percepatan kesembuhan dari mencit yang diinfeksi $P$. berghei (28). Dengan demikian hasil penelitian ini mendukung peranan antioksidan sebagai terapi adjuvant pada infeksi malaria falciparum berat dalam menghambat terjadinya komplikasi.

\section{KESIMPULAN}

1. Inkubasi sel endotel dengan serum penderita malaria berat dan netrofil normal dapat menyebabkan stres oksidatif dengan meningkatkan produksi $\mathrm{ROI}$ sel endotel.

2. Pemberian minyak buah merah (Pandanus conoideus) berbagai konsentrasi $(2,8 \%, 5,7 \%$, dan $11,3 \%)$ pada sel endotel yang dipapar dengan serum penderita malaria berat dan netrofil normal menurunkan stres oksidatif.

3. Efek penghambatan dari kandungan antioksidan minyak buah merah (Pandanus conoideus) terhadap produksi ROI sel endotel dibuktikan dengan adanya korelasi negatif dengan analisis korelasi Spearman's $(p<0,01, r=-1)$.

\section{SARAN}

1. Dapat dilakukan penelitian lebih lanjut dengan menggunakan metode yang bersifat kuantitatif untuk mengukur radikal bebas dan apoptosis sel endotel.

2. Perlu dilakukan penelitian lebih lanjut mengenai efek minyak buah merah secara in vivo dan dosis terapi yang optimal serta uji toksisitas.

3. Perlu dilakukan penelitian lebih lanjut mengenai pengaruh jumlah netrofil terhadap produksi ROI sel endotel.

\section{DAFTAR KEPUSTAKAAN}

1. Brown HW, Neva FA. Basic Clinical Parasitology, 6 th Edition. USA: Prentice- Halllnternational Inc. 1994; 81-103.

2. Lou J, Lucas R, Grau GE. Pathogenesis of Cerebral Malaria: Recent Experimental Data and Possible Applications for Human. Clinical Microbiology Reviews 2001; 14 (4): 810-820.

3. Hunt NH, Kopp M, Stocker R. Free Radicals and Antioxidant in Malaria in Lipid-Soluble Antioxidant: Biochemistry and Clinical Applications. Edited by ASH Ong \& L Packer. Switzerland: Birkhauser Verla. 1992; 337-354.

4. Das BS, Thurnham DI. Plasma Lipid Peroxidation in Plasmodium falciparum Malaria in Lipid -Soluble Antioxidant: Biochemistry and Clinical Applications. Edited by ASH Ong \& L Packer. Switzerland: Birkhauser Verlag. 1992;:397-405.

5. Nakornchai S, Anantavara S. Oxygen Free Radicals in Malaria in Lipid- Soluble Antioxidant: Biochemistry and Clinical Applications. Edited by ASH Ong \& L Packer. Switzerland: Birkhauser Verlag. 1992; 355-362.

6. Kumaratilake LM, Ferrante A. Opsonization and phagocytosis of Plasmodium falciparum merozoites measured by flow cytometry. Clin Diagn Lab Immunol 2001; 7 (1) : 9-13.

7. Halliwel B, Gutteridge JM. Free Radicals in Biology and Medicine. Third Edition. New York Oxford: University Press. 1999. 
8. lyawe HOT, Onigbinde AO. Effect of an Antimalarial and a Micronutrient Supplemention on Respiration Induced Oxidative Stress. Pakistan Journal of Nutrition 2004; 3(6): 318-321.

9. Iskandar A. Efek Sinergis Chloroquin dan N-Acetyl Cystein terhadap Penurunan Derajat Parasitemia, Penurunan Aktifitas Radikal Bebas dan Peningkatan Fagositosis Makrofag Peritoneal Mencit Galur BALB/c selama infeksi Plasmodium berghei. [Thesis]. Malang: Program Pasca Sarjana Universitas Brawijaya. 2005.

10. Hemmer CJ, Lehr HA, Westphal K, Unvericht M, Kratzius M, Reisinger EC. Plasmodium falciparum Malaria: Reduction of Endothelial Cell Apoptosis in vitro. Infect Immun 2005; 73 (3): 1764-1770.

11. Budi MI, Paimin FR. Buah Merah. Jakarta: Penebar Swadaya. 2005.

12. Morgan DML. Isolation and Culture of Humen Umbilical Vein Endothelial Cells in Human Cell Culture Protocols. Edited by Gareth E. Jones. New Jersey: Humana Press. 1996; 101-109.

13. Fitri LE. Analisis Patogenesis Malaria dengan Komplikasi: Tinjauan Molekuler terhadap Peran molekul Adhesi Eritrosit Terinfeksi Plasmodium falciparum Isolat Malang dan Keterlibatan Senyawa Oksigen Reaktif. [Disertasi]. Malang: Program Pasca Sarjana Universitas Brawijaya. 2004.

14. Tjahajati I. Vaksinasi BCG Meningkatkan Aktivitas Fagositosis dan Sekresi Reactive Oxygen Intermediate (ROI) pada Makrofag Peritonium Kucing yang Diinfeksi dengan Mycobacterium tuberculosis. Jurnal Kedokteran Brawijaya 2006; 21(2):71-77.

15. Torre D, Speranza F, Giola M. Role of Th1 and Th2 Cytokines in Immune Response to Uncomplicated Plasmodium falciparum Malaria. Clinical and Diagnostic laboratory Immunology 2002; 9 (2): 348-351.

16. Lyke KE, Burges R, Cissoko Y. Serum Levels of the Proinflamatory Cytokines IL-1 $\beta$, IL-6, IL-8, IL-10, TNF- $\alpha$, and IL12(p70) in Malian Children with Severe Plasmodium falciparum Malaria and Matched Uncomplicated Malaria or Healthy Controls. Infection and Immunity 2004; 72 (10): 5630-5637.

17. Salmon D, Vilde JL, Andrieu B, Simonovic R, lebras J. Role of immune serum and Complement in stimulation of the metabolic burst of human netrophils by Plasmodim falciparum. Infection and Immunity 1986; 51 (6) :801-806.

18. Li J-M, Shah Am. Endothelial cell superoxide generation, regulation and revance for cardiovascular pathophysiology. Am J Physiol Regul Integr Comp Physiol 2004; 287: R1014-R1030.

19. Ray R, Shah AM. NADPH oxidase and endothelial cell function. Clinical Science 2005; 109: 217-226.

20. Takahashi T, Hato F, Yamane T, Fukumasu H, Suzuki K, Ogita S, Nishizawa Y, Kitagawa S. Activation of Human Netrofil by Cytokine-Activated Endothelial Cells. Circulation Research 2001; 88: 422.

21. Van Tits L, Demacker PN, de Graaf J. $\alpha$ - Tocopherol supplementation decreases production of superoxide and cytokines by leukocytes ex vivo in both normolipidemic and hypertriglyceridemic individuals. Am J Clin Nutr 2000; $71: 458$ - 464.

22. Harper L, Nuttal SL, Martin U, and Savage OS. Adjuvant treatment of patients with antineutrophil cytoplasmic antibodyassociated vasculitis with vitamins $E$ and $C$ reduces superoxide production by neutrophils. Rheumatology 2002; 41:274278.

23. Papas AM. Antioxidant Status, Diet, Nutrition, and Health. Washington: CRC press. 1999; 189-211.

24. Chew BP. Role of Carotenoids in The Immune Response. J Dairy Sci 1993; 76:2804-2811.

25. Brigelius-Flohe R, Traber MG. Vitamin E: function and metabolism. FASEB J. 1999; 13: 1145-1155.

26. Ricciarelli R, Zingg J-M, Azzi A. Vitamin E: protective role of a Janus molecule. FASEB J. 2001; 15: 2314-2325.

27. Chen X, Touyz RM, Park JB, Schiffrin EL. Antioxidant Effects of Vitamin C and E are Associated with Altered Activation of Vascular NADPH Oxidase and Superoxide Dismutase in Stroke-Prone SHR. Hypertension 2001; 38 (2): 606-611.

28. Fitri LE, Suhendro W, Murwani S, Muliartha IKG, Ali. Efect of Combined Therapy Using Chloroquine and Vitamin C to The Peritoneal Macrophage Function in BALB/C Strain Mice Infected by Plasmodium berghei. Majalah Kedokteran Universitas Brawijaya Malang Desember 2003; 19 (3): 99-103. 